\title{
Ni-bázisú szuperötvözetek megmunkálhatósága váltólapkás marószerszámok alkalmazásával
}

\section{Machinability of Ni-based Superalloys by Indexable End Mills}

\author{
Kun Krisztián, ${ }^{1}$ Kodácsy János, ${ }^{2}$ Vaczkó Dániel, ${ }^{3}$ Kovács Zsolt Ferenc ${ }^{4}$ \\ Neumann János Egyetem, GAMF Kar, Jármütechnológia Tanszék, Kecskemét, Magyarország \\ ${ }^{1}$ kun.krisztian@gamf.uni-neumann.hu \\ ${ }^{2}$ kodacsy.janos@gamf.uni-neumann.hu \\ ${ }^{3}$ vaczko.daniel@gamf.uni-neumann.hu \\ ${ }^{4}$ kovacs.zsolt@gamf.uni-neumann.hu
}

\begin{abstract}
The subject of the research is the machining of Ni-based super alloys using indexable end mills. The cutting ability of these materials is known to be difficult, even challenging with modern tools, so our goal is to create an efficient technology recommendation on an experimental basis. To this end, we have developed an experimental design, which results are used to determine the optimal technological parameters. This research took place at John Von Neumann University, Department of Vehicle Technology of GAMF Faculty.
\end{abstract}

Keywords: Ni-based superalloy, built-up edge, tool wear.

\section{Összefoglalás}

A kutatás témája a Ni-bázisú szuperötvözetek váltólapkás maróval történő megmunkálása. Mivel ezen anyagok forgácsolhatósága közismerten nehéz, még a modern szerszámok mellett is kihívást jelent, ezért célunk egy hatékonyan alkalmazható technológiai ajánlás létrehozása kísérleti úton. Ennek érdekében kísérlettervet alakítottunk ki, amelynek eredményeit kiértékelve az optimális technológiai változók megállapíthatók. Ennek a megvalósítására a Neumann János Egyetem GAMF Karának Járműtechnológiai Tanszékén került sor.

Kulcsszavak: Ni-szuperötvözet, élrátét, szerszámkopás.

\section{Bevezetés}

A járműiparban, kiváltképp a repüléstechnikához és az űrkutatáshoz kapcsolódó iparágakban egyre szélesebb körű a Ni-bázisú szuperötvözetek felhasználása. A mai, korszerü repülőgépeket szinte kizárólag korunk egyik legfejlettebb energiaátalakító berendezései, a gázturbinák hajtják, de használják őket erőművekben is. A turbina bemeneti részére érkező gáz hőmérséklete nagy teljesítményű sugárhajtóműveknél elérheti az $1650{ }^{\circ} \mathrm{C}$-ot. A nagy hőmérséklet mellett a turbinalapátoknak még percenként akár 10 000-et meghaladó fordulatszámot is el kell vi- selniük. Manapság a turbinákban a legnagyobb hőmérsékleteknek kitett terelőlemezeket és turbinalapátokat különlegesen nagy olvadáspontú nikkelötvözetekből, úgynevezett nikkelalapú szuperötvözetekből készítik [1]. Ezen ötvözetek jellemzője a nagy szilárdság, a rossz hővezető képesség, a paramágnesesség. További előnyük, hogy megőrzik szilárdságukat és ellenállnak a korróziónak extrém nagy hőmérsékleteken is. A belőlük készült alkatrészeket gyakran forgácsolják annak ellenére, hogy tulajdonságaik alapján a különösen nehezen forgácsolható anyagok közé sorolhatók. Forgácsolhatóságuk még a modern, váltólapkás szerszámok mellett is nagy kihí- 
vást jelent. Jellemzően az intenzív szerszámkopás és a lapkatörés jelenti a legnagyobb problémát. Az ismertetésre kerülő kísérleti munka során a GTD-111 márkanevü szuperötvözet marási lehetőségeit vizsgáltuk [2-7].

\subsection{A kísérletek során alkalmazott anyag és szerszámok}

A megfelelő szerszámok kiválasztása minden esetben nagy odafigyelést és szakértelmet kíván. Egy rosszul kiválasztott szerszám instabil gyártáshoz, szerszámtöréshez vezethet, illetve megnövelheti a munkadarab gyártásának költségeit. Egy jó döntéssel növelhető a gyártás biztonsága, termelékenysége, valamint csökkenthetők a ciklusidők és a szerszámgép igénybevétele is [8]. Számos szerszámanyag ismert, ami alkalmas lehet Ni-szuperötvözet megmunkálására. Általánosan elfogadott tény, hogy szikraforgácsolással könnyen meg tudjuk munkálni [9], viszont ennek időigénye nagy, ezért végeznek kutatásokat alternatív lehetőségek [10] és szerszámanyagok - például kerámia - feltárására [11]. A szerszámanyagok mellett a forgácsoláskor alkalmazott megmunkálási stratégia is fontos tényezőként jelenhet meg [12, 13].

\subsubsection{A kísérlet során felhasznált anyag}

A kutatásban vizsgált GTD-111 Ni-bázisú szuperötvözet, amelyet különleges, vákuumos öntéssel állítottak elő. Az anyag kémiai összetétele az 1. táblázatban található [14].

Forgácsolhatóságát tekintve a szuperötvözetek közt is az egyik legnehezebben forgácsolható anyag. Rossz hővezetés jellemzi, ami forgácsolásnál nagyon kritikus, mivel ideális esetben a leválasztott anyag (forgács) viszi el a legtöbb hőt,

1. táblázat. A GTD-111 szuperötvözet kémiai összetétele [14]

\begin{tabular}{|c|c|}
\hline $\begin{array}{c}\text { Ötvözök } \\
\text { (GTD-111) }\end{array}$ & $\begin{array}{c}\text { Összetétel } \\
\text { (\%) }\end{array}$ \\
\hline $\mathrm{Ni}$ & 62,37 \\
\hline $\mathrm{C}$ & 0,08 \\
\hline $\mathrm{Cr}$ & 13,7 \\
\hline $\mathrm{Co}$ & 9 \\
\hline $\mathrm{Al}$ & 2,8 \\
\hline $\mathrm{Ti}$ & 4,7 \\
\hline $\mathrm{W}$ & 3,5 \\
\hline $\mathrm{Mo}$ & 1,4 \\
\hline $\mathrm{Ta}$ & 2,4 \\
\hline $\mathrm{B}$ & 0,05 \\
\hline
\end{tabular}

továbbá nagyon stabil és nagy teljesítményű szerszámgépre van szüksége, mivel nagy a fellépő forgácsolási erő. A GTD-111 jelü Ni-bázisú anyag forgácsolásának szempontjából fontos mechanikai és fizikai tulajdonságok a 2. táblázatban találhatók.

2. táblázat. A GTD-111 mechanikai és fizikai tulajdonságai [14]

\begin{tabular}{|l|c|}
\hline Szakítószilárdság, $\mathrm{R}_{\mathrm{m}}(\mathrm{MPa})$ & 1310 \\
\hline Nyúlás, $\mathrm{A}_{5}(\%)$ & 5 \\
\hline Kontrakció, Z (\%) & 5 \\
\hline Keménység & HRC 41,4 \\
\hline Hővezető képesség $20^{\circ} \mathrm{C}-\mathrm{on}, \lambda(\mathrm{W} /(\mathrm{m} \cdot \mathrm{K}))$ & 12,56 \\
\hline
\end{tabular}

\subsubsection{A szerszámválasztás szempontjai}

A váltólapkás marók három fő részből állnak: a szerszámtestből, a lapkából és a lapka bevonatából. Először a váltólapka bevonatát választottuk ki a megmunkálni kívánt anyaghoz, a TaeguTec® cég által gyártott bevonatok közül. Ehhez rendelkezésre állt egy bevonatválasztó segédlet, amelyben rangsorolva van az összes, marásra kifejlesztett TaeguTec® bevonat. Ezek az 1. ábrán látható táblázatban vannak elrendezve a szívósságuk és a keménységük alapján, alulról felfele haladva. Esetünkben a GTD-111 Ni-bázisú szuperötvözet, amely az S csoportba tartozik, amit barna szín jelöl a táblázatban.

A segédlet alapján a következő bevonatok jöhetnek szóba: TT9080, TT9030, TT8080 és TT8020. Mind a négy választható bevonatminőség PVD (Physical Vapor Deposition) bevonat, amelyek között a különbség a lapkára felvitt bevonati rétegek minősége és azok felvitelének sorrendje. A pontos bevonat kiválasztása a lapkageometria meghatározásánál fog megtörténni, mivel a gyártó nem gyárt le egy adott geometriát mindenfajta bevonattal. A következő lépésként kiválasztottuk a lehetséges szerszámokat és lapkákat. A kísérletben $\emptyset 20$ mm-es sarokmaróra van szükség, amelyet Weldon-megfogással fogunk be, és ehhez olyan lapkát kell párosítani, amely $3 \mathrm{~mm}$-es fogásmélységre képes. Ennek kiválasztására is nagy segítséget kapunk a gyártótól. A szerszám kiválasztásánál figyelembe vettük a gyakorlatban használt lapkageometriákat, amelyek alapján a 0 fok hátszögű lapkákra esett a választás, mivel ezeknek a lapkáknak jóval stabilabb és merevebb a forgácsolóéke. Ezen információk alapján a katalógusban a 4NKT 060308R-ML és 6NKU 040308RM lapkákra esett a választás (2. ábra). 


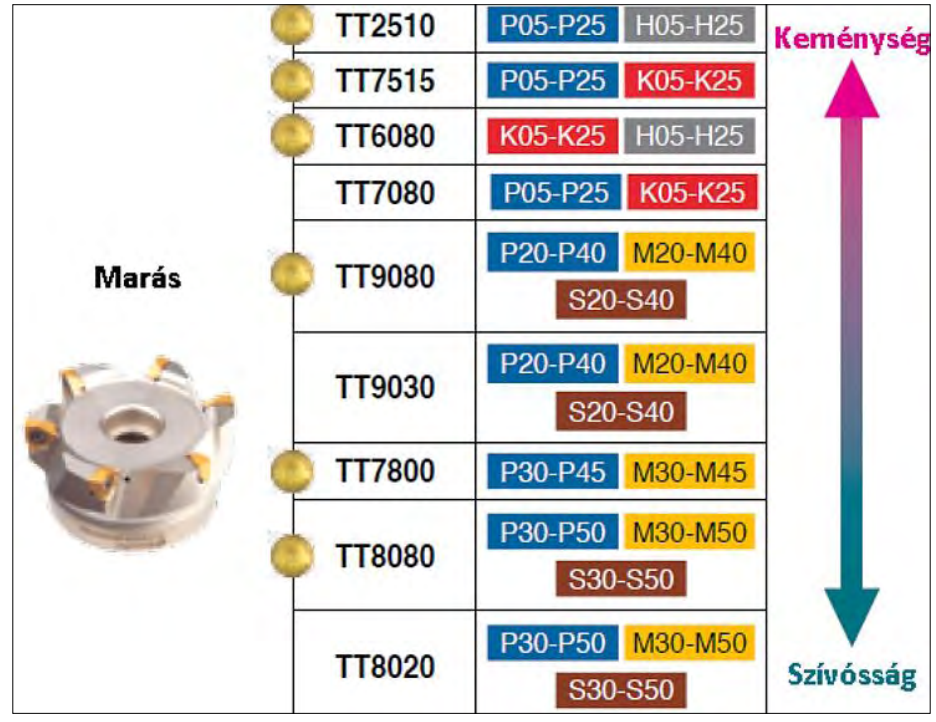

1. ábra. A TaeguTec bevonatválasztó segédlete [15]

A lapkák választása után két olyan bevonattípust választottunk a lapkákhoz, melyek nagymértékben eltérnek egymástól tulajdonságaikban. Így a TT9080 és TT8080 minőségü bevonatokat választottuk.

Mivel a kísérletek során nagyoló megmunkálásra fogjuk tesztelni a szerszámokat, ezért a katalógus ajánlása alapján a TT8080 bevonatot választottuk. Ezt követően a lapkákhoz kiválasztottuk a Ø20 mm-es, Weldon-befogású marókat. Mivel mind a két lapkageometriához azonos fogszámú szerszámot terveztünk használni, ezért a 3 fogszámú marók mellett döntöttünk. Ezek jelölése 4N TE90-320-W20-06, amely a 4NKT 060308R-ML lapkához való marószár és 6N TE90-320-W20-04, ami a 6NKU 040308R-M lapkához való maró (3. ábra).

A kísérletek során a szerszámokat „A” és „B” szerszám néven különböztettük meg egymástól. Az „A” szerszám néven a 4NKT 060308R-ML típusú lapkát és a hozzá tartozó 4N TE90-320-W20-06 marószárat, míg a „B” szerszám néven 6NKU 040308RM típusú lapkát és a hozzá tartozó 6N TE90-320-W20-04 marószárat jelölte.

\section{A kísérletterv elkészítése}

A kísérletek elvégzéséhez Taguchi-módszert alkalmaztunk, melynek kísérletterve a Minitab17 szoftver segítségével készült. Ez a kísérlettervezési módszer segít megtalálni a kísérleti eredményre ható, legbefolyásolóbb faktorokat és azok lehetséges összes kombinációját, valamint mindezek hatását a kísérleti eredményre. Segíti megtalálni az optimális eredményt hozó faktorkom-

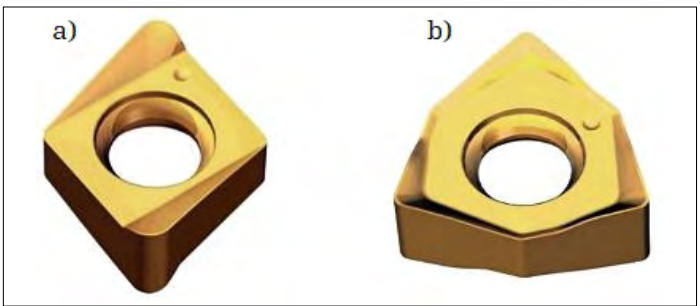

2. ábra. a) 4NKT 060308R-ML és b) 6NKU 040308R-M lapkák [16]

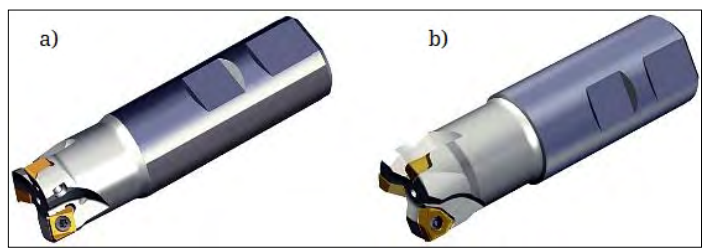

3. ábra. a) 6N TE90-320-W20-04 és b) 6NKU 040308R-M marószerszámok [16]

binációt. A marási faktorokhoz a szinteket, azon belül a forgácsolási sebesség $\left(\mathrm{v}_{\mathrm{c}}\right)$ és a fogankénti előtolás (f f $_{\mathrm{z}}$ szintjeit a TaeguTec ${ }^{\circledR}$ katalógusa alapján adtuk meg.

3. táblázat. Marási faktorok és szintek a kísérletek tervezéséhez

\begin{tabular}{|l|l|c|c|c|c|}
\hline \multirow{2}{*}{\multicolumn{2}{|c|}{}} & \multicolumn{4}{c|}{ Szintek } \\
\cline { 3 - 6 } & $\mathbf{1}$ & $\mathbf{2}$ & $\mathbf{3}$ & $\mathbf{4}$ \\
\hline $\mathrm{A}$ & $\mathrm{v}_{\mathrm{c}}(\mathrm{m} / \mathrm{min})$ & 10 & 20 & 30 & 40 \\
\hline $\mathrm{B}$ & $\mathrm{f}_{\mathrm{z}}(\mathrm{mm} / \mathrm{fog})$ & 0,03 & 0,07 & 0,11 & 0,15 \\
\hline C & Szerszám & \multicolumn{2}{|c|}{ A geometria } & \multicolumn{3}{c|}{ B geometria } \\
\hline
\end{tabular}




\subsection{A forgácsolási kísérletterv részletei}

A munkadarabot gépsatu segítségével rögzítettük az EML850D típusú CNC megmunkálóközpont asztalához. A satuban a munkadarabot úgy rögzítettük, hogy a homlokfelülete a satuból $14 \mathrm{~mm}$-t állt ki (4. ábra).

A kifogás méretét úgy határoztuk meg, hogy adott volt a $3 \mathrm{~mm}$-es fogásmélység, amit nyolcszor fogunk megismételni az „A” és a „B” szerszámmal egyaránt a munkadarab 130 mm-es hosszán. Mivel a 24 mm-es mélység már majdnem sok az egyik szerszámnak a geometriájából adódóan, valamint a forgács távozása is nehezebb lett volna a $24 \mathrm{~mm}$ mély hornyokból, így elfeleztük ezt az értéket. Ezáltal egy szerszámmal két-két hornyot munkáltunk ki, 12-12 mm-es mélységben, így optimális a munkadarab megfogása, és könnyebb a forgács távozása is. A részletes kísérletterv technológiai változóit a 4. táblázat foglalja össze.

4. táblázat. A GTD-111 anyag marásához használt Taguchi-kísérletterv

\begin{tabular}{|c|c|c|c|c|}
\hline Ssz. & $\begin{array}{c}\mathbf{v}_{\mathbf{c}} \\
(\mathbf{m} / \mathbf{m i n})\end{array}$ & $\begin{array}{c}\mathbf{f}_{\mathbf{z}} \\
(\mathbf{m m} / \mathbf{f o g})\end{array}$ & Szerszám & Jelölés* \\
\hline 1. & 10 & 0,03 & A & AB1 \\
\hline 2. & 10 & 0,07 & B & BB1 \\
\hline 3. & 10 & 0,11 & A & AB2 \\
\hline 4. & 10 & 0,15 & B & BB2 \\
\hline 5. & 20 & 0,03 & B & BB3 \\
\hline 6. & 20 & 0,07 & A & AB3 \\
\hline 7. & 20 & 0,11 & B & BB4 \\
\hline 8. & 20 & 0,15 & A & AB4 \\
\hline 9. & 30 & 0,03 & A & AJ1 \\
\hline 10. & 30 & 0,07 & B & BJ1 \\
\hline 11. & 30 & 0,11 & A & AJ2 \\
\hline 12. & 30 & 0,15 & B & BJ2 \\
\hline 13. & 40 & 0,03 & B & BJ3 \\
\hline 14. & 40 & 0,07 & A & AJ3 \\
\hline 15. & 40 & 0,11 & B & BJ4 \\
\hline 16. & 40 & 0,15 & A & AJ4 \\
\hline
\end{tabular}

${ }^{*}$ A hornyok jelölése:

$\mathrm{AB}$ - „A” szerszám és „B” bal oldali horony BB - „B” szerszám és „B” bal oldali horony AJ - „A” szerszám és „J” jobb oldali horony BJ - „B” szerszám és „,” jobb oldali horony

\section{Kiértékelés}

A lapkakopások kiértékeléséhez létrehoztunk egy szempontlistát, amelyet a teszteknél a tapasztaltak és az elvárt kritériumok alapján állítottunk össze. A szempontlista 1-től 9-ig értékel, ezt a listát az 5. táblázat foglalja össze.

A legjobb kísérleti eredménynek az AB1 jelű bizonyult. A szerszám lapkáiról készült mikroszkópi képet az 5. ábra mutatja. A lapkák homlok- és hátkopása egyaránt egyenletes. A lapka homlokfelületén jól látható, hogy a bevonat lekopott, de egyéb sérülés nincs a lapkán.

Az áttekinthetőség érdekében készült a 6. táblázat, amely összefoglalja a kísérlettervben szereplő technológiai változóknak az 5. táblázat szempontrendszere szerinti értékelését.

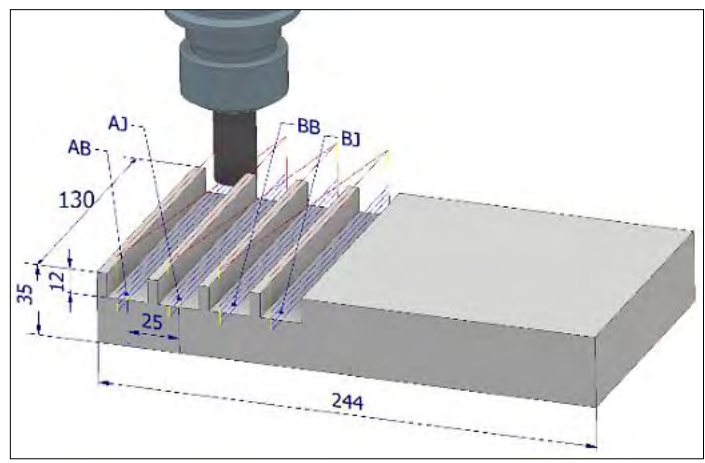

4. ábra. A kísérlet ábrázolása CAD szoftver segítségével

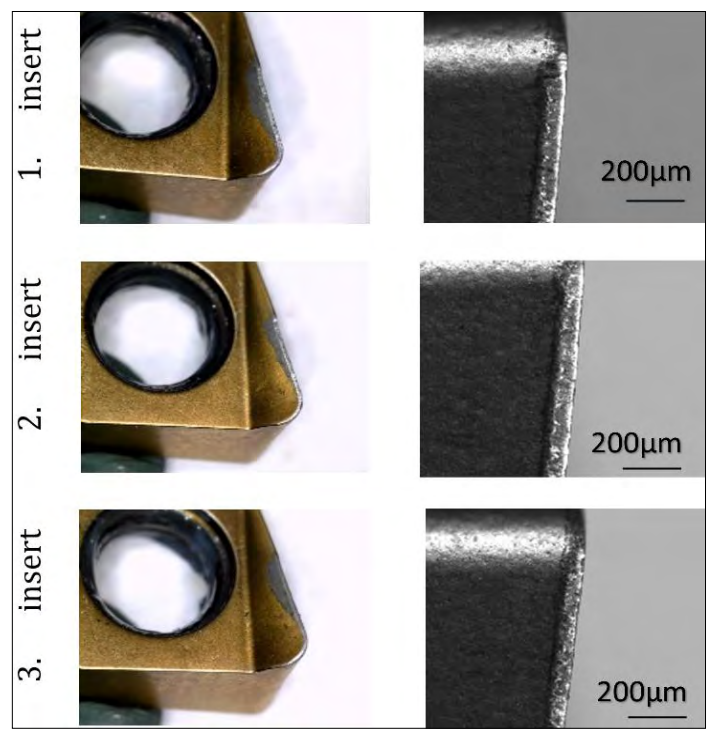

5. ábra. Az AB1 jelü kísérletnél használt „A” jelü szerszám lapkái forgácsolás után és az élek mikroszkópi felvételei 
5. táblázat. Használt váltólapkák osztályozási szempontjai

\begin{tabular}{|c|l|}
\hline Érték & \multicolumn{1}{|c|}{ Szempont } \\
\hline 1 & $\begin{array}{l}\text { Nem tudott végigmenni a megmunkálási hosz- } \\
\text { szon. }\end{array}$ \\
\hline 2 & $\begin{array}{l}\text { Végigment a megmunkálási hosszon, de kriti- } \\
\text { kusan kitöredezett és eltörött a lapka. }\end{array}$ \\
\hline 3 & $\begin{array}{l}\text { Végigment a megmunkálási hosszon, de kri- } \\
\text { tikusan kitöredezett a lapka forgácsolóéle, és } \\
\text { lepattant a hátoldala. }\end{array}$ \\
\hline 4 & $\begin{array}{l}\text { Végigment a megmunkálási hosszon, de kitöre- } \\
\text { dezett és eltörött a lapka. }\end{array}$ \\
\hline 5 & $\begin{array}{l}\text { Végigment a megmunkálási hosszon, de kitö- } \\
\text { redezett a lapka forgácsolóéle, és lepattant a } \\
\text { hátoldala. }\end{array}$ \\
\hline 6 & $\begin{array}{l}\text { Végigment a megmunkálási hosszon, de kitöre- } \\
\text { dezett a lapka forgácsolóéle. }\end{array}$ \\
\hline 7 & $\begin{array}{l}\text { Végigment a megmunkálási szakaszon, de le- } \\
\text { pattant a lapka hátoldala. }\end{array}$ \\
\hline 8 & $\begin{array}{l}\text { Végigment a megmunkálási hosszon, és jelen- } \\
\text { tős a kopás. }\end{array}$ \\
\hline 9 & $\begin{array}{l}\text { Végigment a megmunkálási hosszon, és egyen- } \\
\text { letesen kopott. }\end{array}$ \\
\hline
\end{tabular}

\section{4. Összegzés}

A forgácsolás során a legnagyobb hatással a szerszám élettartamára a forgácsolási sebesség $\left(\mathrm{v}_{\mathrm{c}}\right)$ volt, majd ezt követte a fogankénti előtolás (f). Megfigyelhető, hogy a szerszámgeometria hatása elhanyagolható mértékben befolyásolta az éltartamot.

A leghatékonyabban alkalmazható technológiai változók a kísérletekből kapott értékekkel:

- forgácsolási sebesség $\mathrm{v}_{\mathrm{c}}=10 \mathrm{~m} / \mathrm{min}$,

- fogankénti előtolás $\mathrm{f}_{\mathrm{z}}=0,03 \mathrm{~mm} / \mathrm{fog}$,

- a szerszámgeometria pedig az „A” jelű szerszám.

Ezen értékekkel készült horony látható a 6. ábrán.

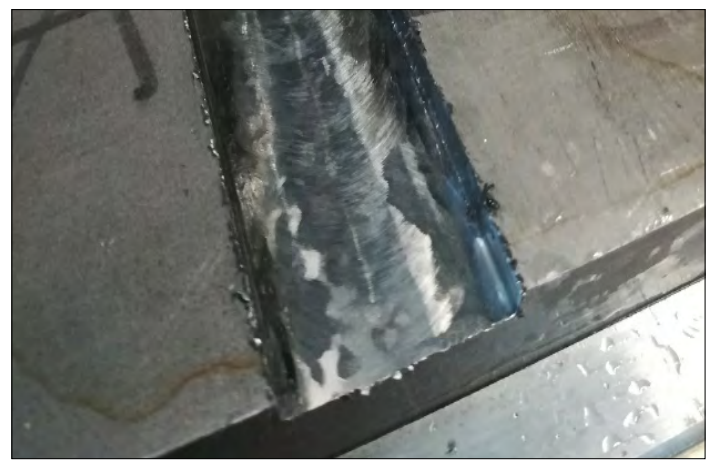

6. ábra. Az AB1-es horony felülete és a képződött sorja
6. táblázat. A kísérlettervben szereplő technológiai változók kiértékelése a szempontrendszer szerint

\begin{tabular}{|c|c|c|c|c|}
\hline$\#$ & $\begin{array}{c}\mathbf{v}_{\mathbf{c}} \\
(\mathbf{m} / \mathbf{m i n})\end{array}$ & $\begin{array}{c}\mathbf{f}_{\mathbf{z}} \\
(\mathbf{m m} / \mathbf{f o g})\end{array}$ & Szerszám & Érték \\
\hline AB1 & 10 & 0,03 & A & $\mathbf{9}$ \\
\hline AB2 & 10 & 0,11 & A & 5 \\
\hline AB3 & 20 & 0,07 & A & 6 \\
\hline AB4 & 20 & 0,15 & A & 2 \\
\hline BB1 & 10 & 0,07 & B & 7 \\
\hline BB2 & 10 & 0,15 & B & 4 \\
\hline BB3 & 20 & 0,03 & B & $\mathbf{8}$ \\
\hline BB4 & 20 & 0,11 & B & 5 \\
\hline AJ1 & 30 & 0,03 & A & $\mathbf{8}$ \\
\hline AJ2 & 30 & 0,11 & A & 1 \\
\hline AJ3 & 40 & 0,07 & A & 1 \\
\hline AJ4 & 40 & 0,15 & A & 1 \\
\hline BJ1 & 30 & 0,07 & B & 3 \\
\hline BJ2 & 30 & 0,15 & B & 1 \\
\hline BJ3 & 40 & 0,03 & B & 1 \\
\hline BJ4 & 40 & 0,11 & B & 1 \\
\hline
\end{tabular}

\section{Köszönetnyilvánítás}

Köszönettel tartozunk a kutatás támogatásáért, amely az EFOP-3.6.1-16-2016-00006 A kutatási potenciál fejlesztése és bővítése a Neumann János Egyetemen pályázat keretében valósult meg. A projekt a Magyar Állam és az Európai Unió támogatásával, az Európai Szociális Alap társfinanszírozásával, a Széchenyi 2020 program keretében valósul meg.

\section{Szakirodalmi hivatkozások}

[1] Sajjadi S. A., Nategh S., Isac M., Zebarjad S. M.: Tensile deformation mechanisms at different temperatures in the Ni-base superalloy GTD-111. Journal of Materials Processing Technology 155-156. (2004) 1900-1904. https://doi.org/10.1016/j.jmatprotec.2004.04.273

[2] Bhadeshia H. K. D. H.: Recrystallisation of practical mechanically alloyed iron-base and nickel-base superalloys. Materials Science and Engineering A 223. (1997) 64-77. https://doi.org/10.1016/S0921-5093(96)10507-4

[3] Kodácsy J., Viharos Zs. J., Kovács Zs.: A forgácsolhatóság meghatározásának módszerei Ni-bázisú szuperötvözetek horonymaráskor. Gépgyártás 55(2). (2015) 125-129.

[4] Zhu D., Zhang X., Ding H.: Tool wear characteristics in machining of nickel-based superalloys. International Journal of Machine Tools \& Manufacture 64. (2013) 60-77. https://doi.org/10.1016/j.ijmachtools.2012.08.001 
[5] Lendvai János: Szuperötvözet egykristályokdrágakövek a gázturbinákban. Fizikai Szemle 2006/10.

[6] Qi Y., Zhang Y., Zhang W., Gao J., Yuan Z., Bu W., Li Y., Guo S.: Hydrogen storage thermodynamics and kinetics of RE-Mg-Ni-based alloys prepared by mechanical milling. International Journal of Hydrogen Energy 42/29. (2017) 18473-18483. https://doi.org/10.1016/j.renene.2018.07.134

[7] Ulutan D., Arisoy Y. M., Özel T., Mears L.: Empirical modeling of residual stress profile in machining nickel based superalloys using the sinusoidal decay function. Procedia CIRP 13. (2014) 365-370. https://doi.org/10.1016/j.procir.2014.04.062

[8] Mali H. S., Unune D. R.: Machinability of Nickel-Based Superalloys: An Overview. Reference Module in Materials Science and Materials Engineering, (2017). https://doi.org/10.1016/B978-0-12-803581-8.09817-9

[9] Kang X., Tang W.: Micro-drilling in ceramic-coated Ni-superalloy by electrochemical discharge machining. Journal of Materials Processing Technology, 255. (2018) 656-664. https://doi.org/10.1016/j.jmatprotec.2018.01.014

[10] Obikawa T., Yamaguchi M., Funai K., Kamata Y., Yamada S.: Air jet assisted machining of nickel-base superalloy. International Journal of Machine Tools \& Manufacture 61. (2012) 20-26. https://doi.org/10.1016/j.ijmachtools.2012.05.005

[11] Sajgalik M., Czan A., Drbul M., Danis I., Miklos M., Babik O., Joch R.: Identification of Technological Parameters when Machining Ni-Alloys by Monolithic Ceramic Milling Tool. Procedia Manufacturing 14. (2017) 51-57. https://doi.org/10.1016/j.promfg.2017.11.006

[12] Pleta A., Mears L.: Cutting Force Investigation of Trochoidal Milling in Nickel-Based Superalloy. Procedia Manufacturing 5. (2016) 1348-1356. https://doi.org/10.1016/j.promfg.2016.08.105

[13] Luo M., Lou H., Zhang D., Tang K.: Improving tool life in multi-axis milling of Ni-based superalloy with ball-end cutter based on the active cutting edge shift strategy. Journal of Materials Processing Technology 252. (2018) 105-115. https://doi.org/10.1016/j.jmatprotec.2017.09.010

[14] Raznjevic K.: Hőtechnikai táblázatok. Műszaki könyvkiadó, Budapest, 1964.

[15] TaeguTech: Grade Chart.(letöltve:2019. május 12.) http://www.taegutec.co.kr/Media/DownloadFiles/ grade_en.pdf

[16] TaeguTec: Elektronikus katalógus. (letöltve: 2019. május 12.) http://www.imc-companies.com/TaeguTec/ttkCatalog/Index.aspx 